\title{
HUBUNGAN PERILAKU KELUARGA DALAM UPAYA PENCEGAHAN DEMAM BERDARAH DENGUE (DBD) TERHADAP KEBERADAAN JENTIK NYAMUK DI WILAYAH KERJA PUSKESMAS SAWAH LEBAR KOTA BENGKULU
}

\section{THE RELATIONSHIP OF FAMILY BEHAVIOR IN THE PREVENTION OF DENGUE HEMORRHAGIC FEVER (DHF) ON THE EXISTENCE OF MOSQUITO TYPES IN THE WORK AREA OF THE HEALTH CENTER OF BENGKULU CITY}

\author{
Oleh: \\ Hasan Husin ${ }^{1}$, Riska Yanuarti2 ${ }^{2}$ dan Mutia Ade Fandini ${ }^{3}$ \\ 1,2Dosen Prodi Kesehatan Masyarakat Fikes Universitas Muhammadiyah Bengkulu \\ ${ }^{3}$ Alumni Prodi Kesehatan Masyarakat Fikes Uiversitas muhammadiyah Bengkulu \\ Email: hasanhusin355@gmail.com
}

\begin{abstract}
The number of cases of Dengue Fever that occurred in Bengkulu Province 2018 reached 1,439 cases consisting of 765 men and 674 women. The most cases occurred in Bengkulu City with 427 cases and the highest was in Sawah Lebar Bengkulu Health Center with 33 cases. Research purposes to find out the family relationship with the challenges of dengue bleeding (DHF) to discuss mosquito larvae in the Sawah Lebar Health Center in Bengkulu City. This research uses observational analytic research with cross sectional study design. The sample in this study amounted to 66 people in the working area of Sawah Lebar Health Center in Bengkulu City.Data analysis using Chi Square test. The results of the study of 66 respondents were 7 people who knew less, 31 people enough and 28 people knew well. There are 18 people who do not support and 48 people who support. Then there are 18 less actions and 48 good actions. Out of 66 people answered 14 people with mosquito larvae and 52 people without mosquito larvae. Related to the relationship of knowledge, attitudes and family actions in an effort to overcome dengue hemorrhagic fever (DHF) on the needs of mosquito larvae in the Sawah Lebar Health Center in Bengkulu City. $(p<0,005)$ Prevention efforts are neededDengue Fever by being able to provide education or health knowledge about efforts to prevent dengue hemorrhagic fever (DHF) on the presence of mosquito larvae in the Work Area of Sawah Lebar Health Center in Bengkulu City.
\end{abstract}

Keywords: Knowledge, Attitude, Action, Mosquito larvae

\begin{abstract}
ABSTRAK
Peningkatan Kasus Demam Berdarah Dengue (DBD) di provinsi Bengkulu tahun 2018 mencapai 1.439 kasus terdiiri dari 765 laki dan 674 perempuan. Kasus terbanyak terjadi di Kota Bengkulu yaitu 427 kasusu dan tertinggi di Puskesmas Sawah Lebar Bengkulu sebanyak 33 Kasus.Tujuan Penelitian ini adalah untuk mengetahui hubungan perilaku keluarga dalam upaya pencegahan demam berdarah dengue (DBD) terhadap keberadaan jentik nyamukdi Wilayah Kerja Puskesmas Sawah Lebar Kota Bengkulu. Penelitian ini menggunakan rancangan cross sectional.Sampeldiambil mennggunakan simple random samplingsebanyak 66 kepala keluarga di wilayah kerja Puskesmas Sawah Lebar.Analisis data menggunakan uji Chi Square. Hasil penelitian menunjukkan bahwa 10,5\% responden memilikipengetahuan kurang, 37,9\% sikap tidak mendukung, dan 27,3\% memiliki tindakan yang kurang baik. Selanjutnya, 21,2\% rumah ditemukan jentik nyamuk. Hasil analisis bivariatmenunjukkan adanya hubungan pengetahuan, sikap dan tindakan keluarga dalam upaya pencegahan demam berdarah dengue (DBD) terhadap keberadaan jentik nyamuk di Wilayah Kerja Puskesmas Sawah Lebar Kota Bengkulu (nilai $p<0,05$ ).Diperlukan upaya pencegahan Demam Berdarah Dengue dengan dapat memberikan edukasi atau pengetahuan kesehatan tentang upaya
\end{abstract}


pencegahan demam berdarah dengue (DBD) terhadap keberadaan jentik nyamuk di Wilayah Kerja Puskesmas Sawah Lebar Kota Bengkulu.

Kata Kunci :Pengetahuan, Sikap, Tindakan, Keberadaan Jentik Nyamuk

\section{PENDAHULUAN}

Peningkatan Kasus Demam Berdarah Dengue (DBD) selama setengah abad menjadi 30 kali lipat, lebih dari setengah penduduk dunia yakni mencapai 3 milyar memiliki resiko terhadap infeksi dengue denganinsidensi sebanyak 500 juta pertahun. (WHO, 2012)

Demam Berdarah Dengue (DBD) pada dekade terakhir menjadi masalahkesehatan global, ditandai dengan meningkatnya kasus DBD di dunia. WorldHealth Organization (WHO) melaporkan lebih dari 2,5 milyar atau dua perlimapopulasi di dunia beresiko terinfeksi virus dengue. (WHO, 2012).

Kasus Demam Berdarah Dengue (DBD) terus bertambah. Secara nasional, Data sebelumnya pada Januari 2017, jumlah kasus DBD mencapai 13.683 dengan jumlah meninggal dunia 133 jiwa. jumlah kasus hingga Februari 2018 adalah sebanyak 16.692 kasus dengan 169 orang meninggal dunia. Kasus terbanyak ada di wilayah Jawa Timur, Jawa Tengah, NTT, dan Kupang.Jawa Timur masih menduduki jumlah kasus terbanyak di antaranya di Kediri dan ponorogo.(Kemenkes $\mathrm{RI}, 2018$ ).

Kondisi penyakit DBD di Indonesia yang sering menimbulkan wabah dengan angka kesakitan yang masih cukup tinggi, sangat membutuhkan penanganan yang serius. Pengetahuan dari individu, keluarga dan masyarakat tentang penyakit DBD dan cara penanggulangannya sangat penting untuk menurunkan angka kesakitan yang terjadi di masyarakat. (Yasmin,2012)

Banyak faktor yang mempengaruhi kejadian DBD, antara lain pengetahuan, keberadaan jentik, ketersediaan tutup pada tempat penampungan air, frekuensi pengurasan tempat penampungan air. (Yulianto, 2013). Penelitian Istiqomah (2017) menunjukkan sikap, sarana dan prasarana, dukungan kader berhubungan signifikan dengan pencegahan DBD.
Kejadian DBD erat kaitannya dengan faktor lingkungan yang menyebabkan tersedianya tempat-tempat perkembangbiakan vector nyamuk Aedes aegypti, dimana nyamuk Aedes aegyptiberkem-bang biak dalam air tergenang dan terbuka, misal-nya tempat yang cocok untuk berkembang biak ada-lah tong, drum, pot, ember, vas bunga, batang atau daun tanaman, tangki, botol buangan, kaleng, ban bekas dan lain-lain. Tempat perkembangbiakan nya-muk ini berupa genangan air yang tertampung di suatu tempat atau kontainer yang tidak pernah dibersihkan (Warisidi, 2017).

Kasus Demam Berdarah Dengue (DBD) di provinsi Bengkulu tahun 2018 mencapai 1.439 kasus terdiiri dari 765 laki dan 674 perempuan. Kasus terbanyak terjadi di Kota Bengkulu yaitu 427 kasusu Berdasarkan data Profil Kesehatan Dinkes Kota Bengkulu tahun 2017 terdapat 287 kasus, dan meninggal 2 orang terdiri dari laki-laki 142 orang dan perempuan 145 orang. Kasus terbanyak terjadi dipuskesma Sawah Lebar yaitu sebanyak 42 kasus kemudian disusul dengan Puskesmas Basuki Rahmat, Ratu Agung, Nusa Indah dan Pasar ikan.

Tujuan dalam penelitian adalah untuk mengetahui hubungan perilaku keluarga dalam upaya pencegahan demam berdarah dengue (DBD) terhadap keberadaan jentik nyamukdi Wilayah Kerja Puskesmas Sawah Lebar Kota Bengkulu.

\section{METODE PENELITIAN}

Jenis penelitian adalah observasional analitik dengan metode pendekatan cross sectional. penelitian ini yaitu dilakukan pada tanggal 2- 10 agustus 2019 di wilayah kerja Puskesmas Sawah Lebar Kota Bengkulu. Populasi dan sampel dalam penelitian ini adalah 66 orang yang terdiri dari pasien yang pernah menderita penyakit DBD dan yang tidak pernah menderita penyakit DBD. 
Pengumpulan data didapat melalui wawancara pada responden dan observasi keberadaan jentik nyamuk wilayah kerja Puskesmas sawah Lebar Kota Bengkulu. Hipotesis penelitian adalah adanya hubungan perilaku keluarga dalam upaya pencegahan DBD terhadap keberadaan jentik nyamuk di wilayah Puskesmas Sawah Lebar Kota Bengkulu. Data dianalisis dengan menggunakan uji Chi Square.

\section{HASIL PENELITIAN \\ Analisis Univariat}

Untuk mendapatkan gambaran distribusi frekuensi dari variabel independen (pengetahuan, sikap dan tindakan keluarga dalam upaya pencegahan demam berdarah dengue (DBD)) dan variabel dependen (keberadaan jentik nyamuk) di Wilayah Kerja Puskesmas Sawah Lebar Kota Bengkulu.

Tabel 1. Distribusi Frekuensi pengetahuankeluarga dalam upaya pencegahan demam berdarah dengue (DBD) di Wilayah Kerja Puskesmas Sawah Lebar Kota Bengkulu

\begin{tabular}{llcc}
\hline No & Pengetahuan & Frekuensi & $\begin{array}{c}\text { Persentase } \\
(\%)\end{array}$ \\
\hline 1. & Kurang & 7 & 10.6 \\
2. & Cukup & 31 & 47.0 \\
3. & Baik & 28 & 42.4 \\
& Total & 66 & 100.0 \\
\hline
\end{tabular}

Tabel 1 di atas dapat dilihat bahwa distribusi frekuensi pengetahuan dari 66 orang responden terdapat 7 orang $(10,6 \%)$ yang pengetahuan kurang, 31 orang $(47,0 \%)$ pengetahuan cukup dan terdapat 28 orang $(42,4 \%)$ yang pengetahuan baik.

Tabel 2Distribusi FrekuensiSikap Keluarga Dalam Upaya Pencegahan Demam Berdarah Dengue (DBD) di Wilayah Kerja Puskesmas Sawah Lebar Kota Bengkulu

\begin{tabular}{llcc}
\hline No & Sikap & Frekuensi & Persentase (\%) \\
\hline 1. & Tidak mendukung & 25 & 37.9 \\
2. & Mendukung & 41 & 62.1 \\
\hline & Total & 66 & 100.0 \\
\hline
\end{tabular}

Tabel 2 di atas dapat dilihat bahwa distribusi frekuensi sikap dari 66 orang responden terdapat 25 orang $(37,9 \%)$ yang sikap tidak mendukung dan terdapat 41 orang $(62.1 \%)$ yang sikap mendukung.

Tabel 3Distribusi Frekuensi tindakan keluarga dalam upaya pencegahan demam berdarah dengue (DBD) di Wilayah Kerja Puskesmas Sawah Lebar Kota Bengkulu

\begin{tabular}{llcc}
\hline No & Tindakan & Frekuensi & $\begin{array}{c}\text { Persentase } \\
(\%)\end{array}$ \\
\hline 1. & Kurang & 18 & 27.3 \\
2. & Baik & 48 & 72.7 \\
\hline & Total & 66 & 100.0 \\
\hline
\end{tabular}

Tabel 3 di atas dapat dilihat bahwa distribusi frekuensi tindakan dari 66 orang 
responden terdapat 18 orang $(27,3 \%)$ yang tindakan kurang dan terdapat 48 orang

$(72,7 \%)$ yang tindakan baik.

Tabel 4 Distribusi FrekuensiKeberadaan Jentik Nyamuk di Wilayah Kerja Puskesmas Sawah Lebar Kota Bengkulu

\begin{tabular}{llcc}
\hline No & Keberadaan Jentik Nyamuk & Frekuensi & Persentase $(\%)$ \\
\hline 1. & Ada Jentik & 14 & 21.2 \\
2. & Tidak Ada Jentik & 52 & 78.8 \\
\hline & Total & 66 & 100.0 \\
\hline
\end{tabular}

Tabel 4 di atas dapat dilihat bahwa distribusi frekuensi keberadaan jentik nyamuk dari 66 orang responden terdapat 14 orang $(21,2 \%)$ yang ada jentik nyamuk dan terdapat 52 orang $(78,8 \%)$ yang tidak ada jentik nyamuk.

\section{Analisis Bivariat}

Analisis ini dilakukan untuk melihat adanya hubungan dengan variabel independen dan variabel dependen. Dalam penelitian ini digunakan uji analisis data dengan menggunakan uji statistik Chi-square.

Tabel 5. Hubungan pengetahuankeluarga dalam upaya pencegahan demam berdarah dengue (DBD) terhadap keberadaan jentik nyamuk di Wilayah Kerja Puskesmas Sawah Lebar Kota Bengkulu

\begin{tabular}{|c|c|c|c|c|c|c|c|}
\hline \multirow{3}{*}{ Pengetahuan } & \multicolumn{4}{|c|}{ Keberadaan Jentik Nyamuk } & & & \multirow{3}{*}{$\begin{array}{c}P \\
\text { Value }\end{array}$} \\
\hline & \multicolumn{2}{|c|}{$\begin{array}{c}\text { Ada Jentik } \\
\text { Nyamuk }\end{array}$} & \multicolumn{2}{|c|}{$\begin{array}{c}\text { Tidak Ada } \\
\text { Jentik Nyamuk }\end{array}$} & \multicolumn{2}{|c|}{ Total } & \\
\hline & $\mathrm{F}$ & $\%$ & $\mathrm{~F}$ & $\%$ & $F$ & $\%$ & \\
\hline Kurang & 5 & 71,4 & 2 & 28,6 & 7 & 100 & 0,003 \\
\hline Cukup & 5 & 16,1 & 26 & 83,9 & 31 & 100 & \\
\hline Baik & 4 & 14,3 & 24 & 85,7 & 28 & 100 & \\
\hline Total & 14 & 21,2 & 52 & 78,8 & 66 & 100 & \\
\hline
\end{tabular}

Hasil uji pearson Chi-squarediperoleh nilai $p=0,003$ yang menunjukkan adanya hubungan yang signifikan antara pengetahuan keluarga dalam upaya pencegahan demam berdarah dengue (DBD) terhadap keberadaan jentik nyamuk di Wilayah Kerja Puskesmas Sawah Lebar Kota Bengkulu.

Tabel 6 Hubungan sikap keluarga dalam upaya pencegahan demam berdarah dengue (DBD) terhadap keberadaan jentik nyamukdi Wilayah Kerja Puskesmas Sawah Lebar Kota Bengkulu

\begin{tabular}{lcccccccc}
\hline Sikap & \multicolumn{3}{l}{ Keberadaan Jentik Nyamuk } & Total & $\begin{array}{c}\rho \\
\text { Value }\end{array}$ & OR \\
\cline { 2 - 6 } & \multicolumn{2}{l}{$\begin{array}{l}\text { Ada Jentik } \\
\text { Nyamuk }\end{array}$} & \multicolumn{2}{l}{$\begin{array}{l}\text { Tidak Ada } \\
\text { Jentik Nyamuk }\end{array}$} & & & & \\
\hline & $\mathrm{F}$ & $\%$ & $\mathrm{~F}$ & $\%$ & $\mathrm{~F}$ & $\%$ & & \\
\hline Tidak & 13 & 52,0 & 12 & 48,0 & 25 & 100 & 0,000 & 43,33 \\
mendukung & & & & & & & & \\
Mendukung & 1 & 2,4 & 40 & 97,6 & 41 & 100 & & \\
\hline Total & 14 & 21,2 & 52 & 78,8 & 66 & 100 & & \\
\hline
\end{tabular}


Hasil analisisdiperoleh nilai $p=0,000$ yang menunjukkan adanya hubungan yang signifikan antara sikap keluarga dalam upaya pencegahan demam berdarah dengue (DBD) terhadap keberadaan jentik nyamuk di Wilayah Kerja Puskesmas Sawah Lebar Kota
Bengkulu. Selanjutnya nilai $\mathrm{OR}=43,33$ yang artinya orang yang memiliki sikap yang tidak mendukung upaya pencegahan DBD memiliki peluang 43,33 kali lebih besar terdapat jentik nyamuk dibandingkan dengan yang mendukung.

Tabel 7.Hubungan tindakan keluarga dalam upaya pencegahan demam berdarah dengue (DBD) terhadap keberadaan jentik nyamuk di Wilayah Kerja Puskesmas Sawah Lebar Kota Bengkulu

\begin{tabular}{|c|c|c|c|c|c|c|c|c|}
\hline \multirow[t]{3}{*}{ Tindakan } & \multicolumn{4}{|c|}{ Keberadaan Jentik Nyamuk } & \multirow{2}{*}{\multicolumn{2}{|c|}{ Total }} & \multirow{3}{*}{$\begin{array}{c}\rho \\
\text { Value }\end{array}$} & \multirow[t]{3}{*}{ OR } \\
\hline & \multicolumn{2}{|c|}{$\begin{array}{l}\text { Ada Jentik } \\
\text { Nyamuk }\end{array}$} & \multicolumn{2}{|c|}{$\begin{array}{l}\text { Tidak Ada Jentik } \\
\text { Nyamuk }\end{array}$} & & & & \\
\hline & $\mathrm{F}$ & $\%$ & $\mathrm{~F}$ & $\%$ & $\mathrm{~F}$ & $\%$ & & \\
\hline Kurang & 13 & 72,2 & 5 & 27,8 & 18 & 100 & 0,000 & 122,2 \\
\hline Baik & 1 & 2,1 & 47 & 97,9 & 48 & 100 & & \\
\hline Total & 14 & 21,2 & 52 & 78,8 & 66 & 100 & & \\
\hline
\end{tabular}

Hasil analisisdiperoleh nilai $p=0,000$ yang menunjukkan adanya hubungan yang signifikan antara tindakan keluarga dalam upaya pencegahan demam berdarah dengue (DBD) terhadap keberadaan jentik nyamuk di Wilayah Kerja Puskesmas Sawah Lebar. Selanjutnya didapat nilai $\mathrm{OR}=122,2$ yang artinya orang yang tindakan kurang baik dalam pencegahan DBD memiliki peluang 122,2 kali terdapat jentik nyamuk dibandingkan dengan orang yang memiliki tindakan baik.

\section{PEMBAHASAN}

\section{Distribusi Frekuensi Pengetahuan Keluarga} Dalam Upaya Pencegahan Demam Berdarah Dengue (DBD) Di Wilayah Kerja Puskesmas Sawah Lebar Kota Bengkulu

Penelitian ini menunjukkan bahwa responden dengan pengetahuan baik sudah mengetahui tentang pemberantasan sarang nyamuk, mengetahui cara membunuh jentik nyamuk, mengetahui tentang cara dan frekuensi menguras tempat penampungan air.

Hasil penelitian ini sejalan dengan penelitian yang dilakukan oleh Gifari (2017) Hasil pencarian keberadaan jentik Aedes aegypti sebanyak 11 rumah didapatkan jentik dan pada 44 rumah tidak terdapat jentik. Analisis bivariat dilakukan menggunakan uji chi-square pada derajat kepercayaan $95 \%$ dari penelitian ini menunjukkan terdapat hubungan yang bermakna perilaku Gerakan 3M Plus dengan keberadaan jentik Aedes aegypti $(p=0,04)$.

Pengetahuan masyarakat mengenai DBD merupakan langkah awal untuk menentukan tindakan pencegahan dan penanganan penyakit DBD. Banyaknya KLB penyakit DBD seringkali disebabkan minimnya pengetahuan masyarakat mengenai penyakit DBD (Kemenkes RI, 2015).

Penelitian Syarif (2013) menunjukkan bahwa $75 \%$ masyarakat sudah tahu tentang 3M. Pencegahan $3 \mathrm{M}$ ialah jenis pencegahan vector yang paling mudah, murah dan aman, serta mempunyai nilai keberhasilan tinggi yang dapat dilakukan masyarakat.

\section{Distribusi Frekuensi Sikap Keluarga Dalam Upaya Pencegahan Demam Berdarah Dengue (DBD) Di Wilayah Kerja Puskesmas Sawah Lebar Kota Bengkulu}

Hasi penelitian menunjukkan bahwa responden yang bersikap mendukung karena telah memiliki kesadaran dalam menjaga kebersihan lingkungan dengan mengubur kaleng bekas, mengingatkan masyarakat untuk tidak membuang kaleng bekas sembarangan, mengingatkan anggota keluarga, mengajak masyarakat untuk 
memantau adanya jentik nyamuk dilingkungan rumah.

$$
\text { Hasil penelitian Bakta (2014) }
$$

menyatakan bahwa perilaku dalam pemberantasan sarang nyamuk berhubungan dengan pendidikan, pengetahuan dan sikap seseorang secara signifikan. Semakin tinggi pengetahuan seseorang, makan pengetahuannya akan semakin baik, demikian juga dengan sikap. Semakin baik atau mendukung sikap seseorang terhadap perilaku pemberantasan sarang nyamuk, maka perilakunya pun akan semakin baik dalam melaksanakan pemberantasan sarang nyamuk.

Distribusi Frekuensi Tindakan Keluarga Dalam Upaya Pencegahan Demam Berdarah Dengue (DBD) Di Wilayah Kerja Puskesmas Sawah Lebar Kota Bengkulu

Hasil penelitian menunjukkan beberapa tindakan yang dilakukan dalam pencegahan DBD seperti mengubur kaleng bekas, membersihkan tempat penampungan air, mengunakan obat nyamuk atau kelambu, serta membersihkan lingkungan dari botol dan serta kaleng-kaleng bekas dan terlibat dalam pemberantasan sarang nyamuk.

Tindakan merupakan realisasi dari pengetahuan dan sikap yang menjadi perbuatan nyata.Masih banyak masyarakat yang kurang sadar tentang pentingnya kebersihan.Selain itu kurangnya rasa tanggung jawab dalam melakukan pemberantasan sarang nyamuk, kebiasaan masyarakat membuang sampah di sembarang tempat, timbulnya anggapan rsponden mengenai PSN adalah tanggung jawab pemerintah dan rasa malas acuh tak acuh dengan lingkungan sekitar mereka (Azzahra, dkk, 2016).

Penelitian yang dilakukan Ipa (2009) tindakan yang dapat dilakukan dalam pemberatasan DBD antara lain pencegahan gigitan nyamuk, melakukan pemberantasan sarang nyamuk, menguras tempat penampungan air, dan menutup tempat penampungan air.
Distribusi Frekuensi Keberadaan Jentik Nyamuk di Wilayah Kerja Puskesmas Sawah Lebar Kota Bengkulu

Hasil penelitian menunjukkan bahwa keberadaan jenti nyamuk yang ditemukan adalah terdapat pada ban bekas, kolam aquarium, bak mandi dan ember penampungan, kaleng bekas dan botol bekas.

Pemberantasan terhadap jentik aedes aegepty yang dikenal dengan istilah Pemberantasan Sarang Nyamuk Demam Berdarah Dengue (PSN-DBD) Pemberantasan jentik secara fisik dikenal dengan kegiatan 3 $M$, yaitu: Menguras dan menyikat tempat penampungan air (TPA) seperti bak mandi, bak WC, dan lain-lain seminggu sekali secara teratur untuk mencegah perkembangbiakan nyamuk ditempat tersebut. Menutup tempat penampungan air rumah tangga (tempayan, drum, ember, dan lain-lain). Mengubur, menyingkirkan atau memusnahkan barangbarang bekas (kaleng, ban, dan lain-lain) yang dapat menampung air hujan. Selain itu, ditambah dengan cara lain seperti: Mengganti air vas bunga, tempat minum burung atau hewan peliharaan lain, atau tempat-tempat lainnya yang sejenis seminggu sekali. Memperbaiki saluran dan talang air yang tidak lancar atau rusak. (Kemenkes, 2015)

Cara yang paling efektif dalam mencegah penyakit $\mathrm{DBD}$ adalah dengan mengkombinasikan cara-cara diatas, yang disebut dengan "3M Plus". Konsep $3 \mathrm{M}$ yaitu menutup, menguras, menimbun. Selain itu juga melakukan strategi "Plus" seperti memelihara ikan pemakan jentik, menabur larvasida, menggunakan kelambu pada waktu tidur, memasang kasa, menyemprot dengan insektisida, menggunakan lotion anti nyamuk, memasang obat nyamuk, memeriksa jentik berkala sesuai dengan kondisi setempat (Zulkoni, 2011).

Penelitian yang dilakuakan Suyasa (2016) beberapa faktor yang berhubungan dengan keberadaan vector DBD antara lain kepadatan penduduk, mobilitas penduduk, keberadaan pot, saluran air hujan, keberadaan kontainer, tindakan, kebiasaaan menggantung pakain. 
Hubungan Pengetahuan Keluarga Dalam Upaya Pencegahan Demam Berdarah Dengue (DBD) Terhadap Keberadaan Jentik Nyamuk di Wilayah Kerja Puskesmas Sawah Lebar Kota Bengkulu

Hasil penelitian menunjukkan bahwa terdapat hubungan yang signifikan antara pengetahuan keluarga dalam upaya pencegahan demam berdarah dengue (DBD) terhadap keberadaan jentik nyamuk di Wilayah Kerja Puskesmas Sawah Lebar Kota Bengkulu.

Berdasarkan hasil penelitian, responden dengan pengetahuan kurang yang terdapat jentik nyamuk hal ini menunjukan bahwa keberadaan jentik nyamuk berhubungan dengan faktor lainnya diantaranya perilaku, sikap, tindakan, motivasi, kesadaran dalam melakukan pemberantasan sarang nyamuk.

Hasil penelitian sejalan dengan hasil penelitian Marni (2008) bahwa ada hubungan antara pengetahuan dengan tindakan pemberantasan sarang nyamuk demam berdarah dengue. Pengetahuan yang tinggi tidak menjamin seseorang akan melakukan tindakan pemberantasan sarang nyamuk dengan baik. Demam berdarah merupakan masalah kesehatan masyarakat yang sampai saat ini masih menjadi permasalahan yang sangat sulit untuk diberantas. Berdasarkan hasil penelitian yang telah dilakukan tersebut, bahwa agar perilaku atau tindakan manusia atau dalam penelitian ini adalah keluarga, maka diperlukan peningkatan pengetahuan maupun penyamaan persepsi sikap keluarga terhadap gerakan pemberantasan sarang nyamuk.

Penelitian yang dilakukan Santhi (2014) menunjukkan bahwa responden yang memiliki pengetahun yang baik akan melakukan aktifitas pemberantasan sarang nyamuk dengan baik.

Hubungan Sikap Dalam Upaya Pencegahan Demam Berdarah Dengue (DBD) Terhadap Keberadaan Jentik Nyamuk di Wilayah Kerja Puskesmas Sawah Lebar Kota Bengkulu
Hasil penelitian menunjukkan bahwa terdapat hubungan yang signifikan antara sikap keluarga dalam upaya pencegahan demam berdarah dengue (DBD) terhadap keberadaan jentik nyamuk di Wilayah Kerja Puskesmas Sawah Lebar Kota Bengkulu. Hasil penelitian ini sejalan dengan penelitian yang dilakukan Purnama (2013) menunjukkan bahwa variable sikap dan perilaku memiliki kontribusi yang besar terhadap terjadinya infeksi dengue.

Hasil peneitian Iriaty (2017) menunjukkan bahwa terdapat hubungan yang bermakna antara sikap dengan kejadian DBD di wilayah Kerja Psukesmas Guntung Payung.

Hubungan Tindakan Keluarga Dalam Upaya Pencegahan Demam Berdarah Dengue (DBD) Terhadap Keberadaan Jentik Nyamuk di Wilayah Kerja Puskesmas Sawah Lebar Kota Bengkulu

Hasil penelitian menunjukkan bahwa terdapat hubungan yang signifikan antara tindakan keluarga dalam upaya pencegahan demam berdarah dengue (DBD) terhadap keberadaan jentik nyamuk di Wilayah Kerja Puskesmas Sawah Lebar Kota Bengkulu.

Berdasarkan hasil penelitian didapatkan bahwa 1 orang tindakan baik terdapat jentik nyamuk karena faktor lain seperti pengetahuan dan sikap masyarakat tersebut mengenai Demam Berdarah Dengue kurang. Masyarakat mengakui tidak pernah mendapatkan bubuk abate dan tidak rutin melakukan kegiatan gotong royong membersihkan lingkungan rumah.

Penelitian ini menunjukan, dari semua praktik pengendalian DBD yang ada di masyarakat, didukung oleh penelitian Putri (2015) yang menemukan bahwa menguras dan menutup tempat penampungan air sangat berhubungan dengan keberadaan jentik nyamuk. Sehingga diharapkan dengan managemen lingkungan dapat menurunkan jumlah jentik nyamuk dan selanjutnya dapat menurunkan kejadian DBD dalam masyarakat.

Keberhasilan pemberantasan jentik nyamuk juga sangat tergantung kepada 
frekuensi pembersihan jentik (Ananda dan Hidayatullah, 2015).

Penelitian yang dilakukan Irianty (2017) menunjukkan bahwa adanya hubungan antara upaya pencegahan ibu dengan kejadian DBD.

\section{KESIMPULAN}

Hasil penelitian menunjukkan bahwa terdapat hubungan yang signifikan antara pengetahuan, sikap dan tindakan keluarga dalam upaya pencegahan demam berdarah dengue (DBD) terhadap keberadaan jentik nyamuk di Wilayah Kerja Puskesmas Sawah Lebar Kota Bengkulu.

\section{DAFTAR PUSTAKA}

Azzahra, dkk, 2016. Gambaran Pengetahuan Sikap Dan Tindakan Masyarakat Di Kelurahan Antang Kec.Manggala RW VI Tentang Penyalik Demam Berdarah Dengue (Dbd) Kota Makassar tahun 2015. Fakultas Kedokteran Dan IImu Kesehatan UIN alauddin Makassar tahun 2015

Bakta, 2014. Hubungan Antara Pengetahuan dan Sikap Terhadap Perilaku Pemberantasan Sarang Nyamuk (PSN) Sebagai Pencegahan Demam Berdarah Dengue (DBD) di Banjar Badung Desa Melinggih Wilayah Puskesmas Payangan. Skripsi (tidak diterbitkan) Bali: Fakultas Kedokteran Universitas Udayana.

Gifari, 2017. Hubungan Tingkat Pengetahuan dan Perilaku Gerakan 3M Plus dengan Keberadaan Jentik Aedes aegypti. Jurnal Penelitian Fakultas Kedokteran, Universitas Islam Bandung. Bandung Meeting on Global Medicine \& Health (BaMGMH), Vol. 1 No. 1 Tahun 2017

Hidayatullah, 2015. Pemberantasan Sarang Nyamuk Berkorelasi Positif dengan Keberadaan Jentik di Kelurahan Bintaro Kota Mataram. Jurnal Sangkareang Mataram. 2015; Vol. 1(1): 54-58.
Ipa, et al. 2009. Gambaran Pengetahuan, Sikap dan Tindakan Masyarakat serta Hubungannya dengan Kejadian Demam Berdarah Dengue di Kecamatan Pangandaran Kabupaten Ciamis. Jurnal Aspirator. Vol 1 No. 1 Tahun 2009:16-21 Irianty, 2017. Hubungan Sikap dan Upaya Pencegahan Ibu dengan Kejadian Demam Berdarah Dengue (DBD) di Wilayah Kerja Puskesmas Guntung Payung. Jurnal Publikasi Kesehatan Masyarakat Indonesia Vol 4, No 2 Agustus 2017.

Istiqomah, 2012. Faktor-faktor yang Berhubungan dengan Upaya Pencegahan Demam Berdarah Dengue (DBD) pada lbu Rumah Tanggan di Kelurahan Kramas Kota Semarang. Jurnal Kesehatan Masyarakat (ejournal) Vol 5 No. 1 Januari 2017 ISSN:2356-3346.

http://ejournal

s1.undip.ac.id./ndex.php/jkm

Kemenkes RI, 2015, Kemenkes. Kendalikan DBD dengan PSN 3M plus. Februari 2016;diunduh 15 Desember 2017 www.depkes.go.id

Marni, 2008. Hubungan Antara Pengetahuan Dan Sikap Dengan Praktik Ibu Rumah Tangga Dalam Pemberantasan Sarang Nyamuk Demam berdarah Dengue (PSN DBD) Di Kelurahan Oebufu Kecamatan Oebobo Kota Kupang Tahun 2008. Medika Kesehatan Masyarakat.Vol. 03 No. 1 Juni 2008. Diakses pada: 21 September 2012. http://www.

medikakesehatanmasyarakat.files.word press.com.

Purnama, et al. 2013. Pengetahuan, Sikap dan Perilaku Pemberantasan Sarang Nyamuk terhadap Infeksi, Dengue di Kecamatan Denpasar Selatan, Kota Denpasar, Bali. Arc.Com.Health Vol.2 No. 1 Juni 2013. ISSN: 9772302139009 
Putri, 2015. Hubungan Tindakan Pemberantasan SarangNyamuk (PSN) dengan Keberadaan Jentik Vektor Chikungunya di KampungTaratak Paneh Kota Padang. Jurnal Kesehatan Andalas.

Syarif, 2013. Pengetahuan Masyarakat tentang Demam Berdarah Dengue di Desa Maen Kecamatan Likupang Timur Kabupaten Minahasa Utara. Jurnal eBiomedik (eBM) Vol 1. No 1 Maret 2013:349-356

Suyasa, 2016. Hubungn Faktor Lingkungan dan Perilaku Masyarakat dengan Keberadaan Vektor Demam Berdarah Dengue di Wilayah Kerja Puskesmas I Denpasar Selatan.Ecotrophic : Jurnal IImu Lingkungan Vol 3.No.1, ISSN:1907-5626

Warisidi, 2017. Bahaya dan Pencegahan DBD. Bekasi: Mitra Utama

WHO, 2012. World Health Organization. Comprehensive Guidelines for Prevention and Control of Dengue and Dengue Haemorrhagicfever. Revised and Expanded edition. 2011; India: SEARO Technical Publication Series.

WHO. 2012. Global strategy for dengue prevention and control 2012-2020. Geneva: World Health Organisation;.

Yasmin, 2012. Hubungan tindakan pemberantasan sarang nyamuk dengan keberadaan larva vektor nyamuk DBD di kelurahan Lubuk buaya. Jurnal Kesehatan Andalas, Volume 1, pp. 221227.

Yulianto, 2013. Faktor-faktor yang Berhubungan dengan Kejadian Demam Berdarah Dengue di Puskesmas Selatpanjang Kabupaten Kepulauan
Meranti. Jurnal Kesehatan Komunitas Vol 2 No. 3 Nopember 2013.

Zulkoni, 2011. Parasitologi. Yogyakarta: Nuha Medika. 